The values of some other amino-acids may require correction when a more purified preparation of the antispermatogenic fraction is obtained.

As seen in Table 1, analyses of hydrolysed guinea pig testicular and spermatozoal antigens reveal a close similarity in amino-acid content. Injection of less than $5 \mathrm{mg}$ of these antigens in adjuvant into a guinea pig induces aspermatogenesis lasting 6-8 months. The human testicular antigen bears a striking similarity to those from the guinea pig, but the same dose of material does not induce complete aspermatogenesis in the guinea pig. While these analyses support previously reported demonstrations of cross-reactivity between guinea pig and human testicular antigens ${ }^{5}$, the differences in biological activity may be attributed to species specificity.

This work was supported by U.S. Public Health Service grant No. $A I-04152$ and by funds from the Ford Foundation, and the U.S. National Science Foundation.

Charles H. KirkPatrick* Seymour Katsh

Departments of Medicine and Pharmacology,

University of Colorado Medical Center, Denver.

* Special Program Fellow, U.S. Public Health Service.

${ }^{1}$ Freund, J., Lipton, M. M., and Thompson, G. E., J. Exp. Med., 97, 711 (1953).

"Katsh, S., Intern. Arch. Allergy App. Immunol., 15, 172 (1959).

${ }^{3}$ Katsh, S., Intern. Arch. Allergy App. Immunol, 16, 241 (1960).

'Katsh, S., and Katsh, G. F., Fertil. and Steril., 12, 522 (1961).

'Katsh, S., J. Urol., 87, 896 (1962).

'Spackman, D. H., Stein, W. H., and Moore, S., Anal. Chem., 30, 1190 (1958).

\section{Changes in Activity of Transaminase in Dog's Serum due to Lymphœedema of the Liver}

Previously ${ }^{1}$ we examined the changes in activity of transaminase after acute biliary obstruction. This communication records observations regarding changes in serum glutamic-oxaloacetic transaminase (S-GOT) activity due to artificially produced lymphœdema of the liver.

The experiments were carried out on dogs of both sexes under 'Nembutal' anæsthesia $(0.04 \mathrm{~g} / \mathrm{kg}$ body-wt., intravenously). After median laparotomy the portal lymphatic vessels and glands were ligated. Nothing else was done with the control animals except laparotomy. A.ctivity of GOT was determined in the sera of all animals for 3

Table 1. LyMphatic Blockadf

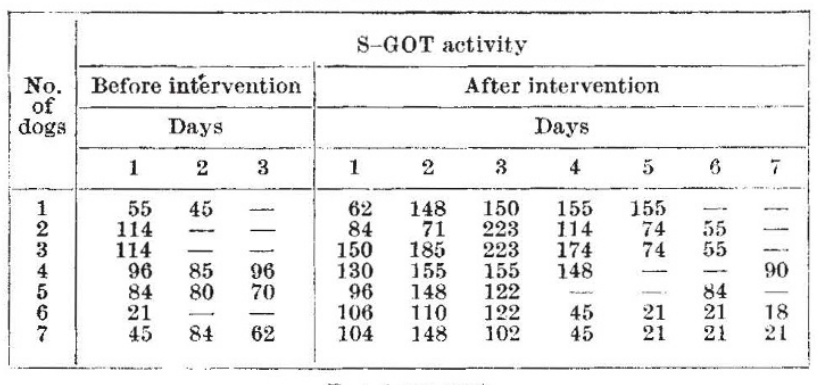

$P<1$ per cent

Table 2. SHAM-OPERATION

\begin{tabular}{|c|c|c|c|c|c|c|c|c|c|c|}
\hline \multirow{4}{*}{$\begin{array}{l}\text { No. } \\
\text { of } \\
\text { dogs }\end{array}$} & \multicolumn{10}{|c|}{ S-GOT activity } \\
\hline & \multicolumn{3}{|c|}{$\begin{array}{c}\text { Before } \\
\text { sham-operation }\end{array}$} & \multicolumn{7}{|c|}{ After sham-operation } \\
\hline & \multicolumn{3}{|c|}{ Days } & \multicolumn{7}{|c|}{ Days } \\
\hline & 1 & 2 & 3 & 1 & 2 & 3 & 4 & 5 & 6 & 7 \\
\hline $\begin{array}{l}1 \\
2 \\
3 \\
4\end{array}$ & $\begin{array}{l}66 \\
70 \\
21 \\
79\end{array}$ & $\begin{array}{r}110 \\
75 \\
71 \\
81\end{array}$ & $\begin{array}{l}\overline{70} \\
74 \\
82\end{array}$ & $\begin{array}{l}71 \\
71 \\
76 \\
86\end{array}$ & $\begin{array}{l}55 \\
80 \\
21 \\
84\end{array}$ & $\begin{array}{l}64 \\
84 \\
22 \\
40\end{array}$ & $\begin{array}{l}62 \\
96 \\
21 \\
35\end{array}$ & $\begin{array}{l}\overline{-} \\
\overline{35} \\
18\end{array}$ & $\begin{array}{l}\overline{ } \\
\overline{22} \\
20\end{array}$ & $\begin{array}{l}\overline{21} \\
21\end{array}$ \\
\hline
\end{tabular}

$P>40$ per cent days before and 7 days after intervention, according to Dubach's method ${ }^{2}$.

The values found in both groups are summarized in Tables 1 and 2. Compared with sham-operation, a significant rise of $\mathrm{S}-\mathrm{GOT}$ activity is found in dogs the lymphatics of which have been blocked.

In 1954 we published our observation on dilatation of lymphatic vessels in the periportal area and around branches of the vena hepatica produced by ligation of the portal lymphaties ${ }^{3,4}$. These alterations are followed by extensive œdema around the v. sublobulares. As a consequence the liver cell columns become compressed. All these obviously affect their metabolism; the changes manifest themselves in the rise of S-GOT activity also. But, since the cedematous state due to disturbed lymph circulation is only temporary, the elevation of S-GOT activity is similarly transitional in these cases.

Institute of Experimental Medical Research, M. PAPP

Hungarian Academy of Sciences, Budapest.

$$
\begin{aligned}
& \text { M. FöLdI } \\
& \text { L. VARGA } \\
& \text { Ö. T. ZOLTÁN }
\end{aligned}
$$

Second Department of Medicine,

University Medical School, Szeged.

\section{P. Braun}

Second Department of Medicine,

Róbert Károly Hospital, Budapest.

${ }^{1}$ Braun, P., Papp, M., and Horváth, I., Nature, 188, 48 (1959).

'Dubach, U. C., Schweiz. med. Wschr., 87, 185 (1957).

${ }^{3}$ Babics, A., Földi, M., Rényi-Vámos, F., Romhányi, Gy., Rusznyák. I. and Szabó, Gy., Magyar Belorvosi Archivum, 7 (in Hungarian), 7 (1954).

${ }^{4}$ Ibid., 7, 86 (1954).

\section{Alteration in Size of the Heart of Late Chick Embryos after Incubation at Varied Temperatures}

We have observed a consistent alteration in the sizo of the heart of chick embryos following the exposure of 11- or 12-day-old embryos to increased or reduced temperatures of incubation for one week. In one series, ninety 11-day-old embryos, which had boen maintained at the normal temperature of $37 \cdot 5^{\circ} \mathrm{C}$, were removed from their incubator, eandled, and divided into three groups of 30 each. One group was placed in an incubator at $32.5^{\circ} \mathrm{C}$, the second returned to $37.5^{\circ} \mathrm{C}$, and the third placed at $42 \cdot 5^{\circ} \mathrm{C}$. On the eighteenth day of incubation live embryos were found as follows: 26 at $32.5^{\circ} \mathrm{C}$. 29 at $37.5^{\circ} \mathrm{C}$ and 18 at $42.5^{\circ} \mathrm{C}$. All the embryos at $42.5^{\circ} \mathrm{C}$ and 20 of the embryos from each of the other two groups were examined. The embryo was removed from its extra-embryonic attachments and weighed. The

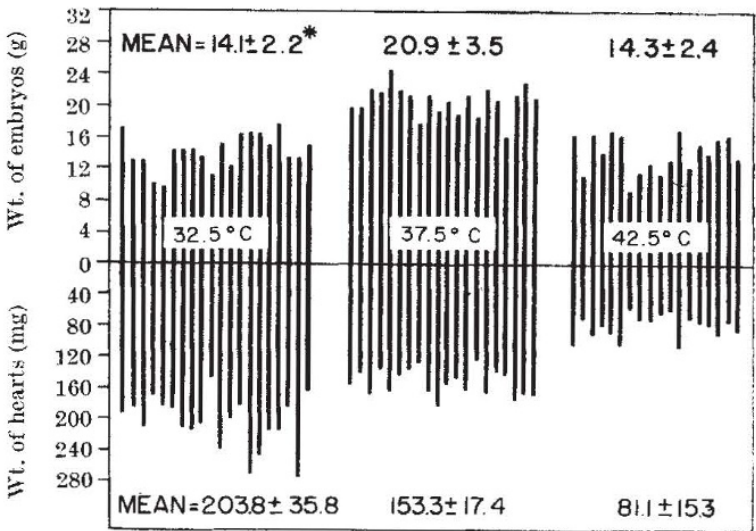

Fig. 1. Tabulation from one experiment of the weight 8 of chick embryos and their hearts on the eighteenth day of incubation, the final week of this period being at the three experimental temperatures 